\title{
Bacterial Quality Assessment of Drinking Water for Layer Chicken Managed Under Battery Cage and Deep Litter Systems from Sokoto Metropolis, Nigeria
}

\author{
SARKINGOBIR, Y; SAMBO, S; TUKUR, U· \\ Department of Biology Shehu Shagari College of Education, Sokoto, Nigeria \\ *Corresponding Author Email: superoxidedismutase594@gmail.com; Tel: 09096266980
}

\begin{abstract}
ABSRACT: This study assessed the bacterial quality of drinking water for layer chicken managed under battery cage (BC) and deep litter (DL) systems in Sokoto Metropolis. A total of 18 samples were collected from the two systems. Serial dilution, spread plate innoculation, colony count, subculturing, gram staining and biochemical characterization were carried out according to standard methods . The mean count concentrations in $\mathrm{BC}\left(1.4 \times 10^{6}, 7.2 \times 10^{6}\right.$ and $\left.3.4 \times 10^{6}\right)$ were relatively higher than those recorded in DL $\left(1.57 \times 10^{7}, 4.52 \times 10^{7}\right.$, and $\left.1.2 \times 10^{6}\right)$. The mean count $(\mathrm{CFU} / \mathrm{ml})$ for BC was 72.11111 and that of DL was 207.4444. The bacteria determined in BC were: : Bacillus species, Micrococcus varians, Corynebacterium xerosis and Lactobacillus fermenti; whereas, those determined in DL were Micrococcus varians, Lactobacillus fermenti, E. coli, and Corynebacterium xerosis; thus E.coli was only recorded in DC, but the rest were found in both BC and DL. In BC, the most frequent was Corynebacterium xerosis, then Micrococcus varians, and lastly Bacillus species and Lactobacillus fermenti ; whereas, in DL Corynebacterium xerosis was also most frequent, then Micrococcus varians ,then the rests. Thus, C. xerosis was the most overall prevalent, then Micrococcus varians, then the rests. This work depicted that water used in the BC and DL systems surveyed contains a higher and diverse concentration of bacteria .This portend of contamination and unsanitary outcome is capable of harming the health, production, and ultimately the public health. More water treatment innovative methods should be use, regular and proper cleaning of farm and drinkers are needed and farmers need to be educated.
\end{abstract}

DOI: https://dx.doi.org/10.4314/jasem.v24i1.14

Copyright: Copyright (C) 2020 Sarkingobir et al. This is an open access article distributed under the Creative Commons Attribution License (CCL), which permits unrestricted use, distribution, and reproduction in any medium, provided the original work is properly cited.

Dates: Received: 30 November 2019; Revised: 20 December 2019; Accepted: 23 December 2019

Keywords: water quality, Corynebacterium xerosis, Lactobacillus fermenti, Sokoto metropolis, Bacillus species

Poultry is a source of food that has been accepted worldwide through the ages. The consumption of poultry products is increasing every year and consumers want a safe product, thus it is pertinent that the poultry producers achieved this goal .Often, poultry products are involved in human foodborne poisoning/diseases posing a considerable cost and threat to public health (International Consultative Group on Food Irradiation, 1999; Ventura daSilva, 2013; Sule and Ilori, 2017). Increase in contacts of poultry with microbes lead to increased contact rates with humans and open new avenues for introduction, proliferation, and transmission of pathogens ; and ultimately more threats to public health (The PEW Charitable Trusts, 2016). Two major poultry systems in Nigeria and Sokoto in particular are the Deep litter (DL), where birds are reared in restricted houses; and Battery cage (BC), where birds are reared in cages(Adam, 2017). Therein, quality water is essential for proper production and safety of poultry health and consequently public health (Folorunso et al., 2004; Abbas et al., 2008).Water make up large proportion of the body of chicken, from 55-75 percent, they cannot thrive without it comparatively to the feed for a long time; that is why they consume circa $1.5-2$ fold of water than feed (Abbas et al., 2008). Water is used in electrolyte replacement therapy, treatment with drugs, and cleaning among others. But the quality of drinking water in poultry can be jeopardized as a result of diverse things .Parable, the source (well or pipe), poor cleaning and maintenance of drinkers, regurgitated feed by the birds, chicken feed, chicken conduct, rearing sites, faeces, antimicrobials or drugs ,and knowledge of rearers (Folorunso et al., 2014; Oviasogie et al., 2016 ). Consequently, the objective of this paper was to determine the bacterial quality of drinking water for layer chicken managed under deep litter (DL) and battery cage (BL) systems in Sokoto, Nigeria.

\section{MATERIALS AND METHODS}

Sample collection: A total of 18 samples were collected randomly from 3 farms of DL and BC in Sokoto.

Sterilization, and Preparation of media: All glass wares were sterilized using standard methods outlined in Oviasogie et al .,(2016).Nutrient agar was prepared according to the standard procedure outlined by Microbiology Society (2016).Simmons Citrate agar, 
Triple Sugar Iron agar and urea agar were prepared based on methods reported in HiMedia Laboratories (2019), HiMedia Laboratories (2015), and Downes (2001) respectively. Indole agar was prepared according to protocols stated by MacWilliams (2009).

Microbial Analysis: Serial dilution, inoculation (spread plate method), bacterial counting, gram staining, and subculturing were performed based on standard methods outlined by Folorunso et al., (2014), Cheesbrough (2009), and Microbiology Society (2016).Biochemical Characterization of microbes was carried out according to Cheesbrough (2009).

Statistical Analyses: Data was analyzed using descriptive statistics (percentage, range, means, and standard deviation).T-test was carried out to compare the 2 housing systems using Statistical Analysis Software (SAS, 2002).

\section{RESULTS AND DISCUSSIONS}

Table 1 has shown the bacterial count between weeks 1-3 from samples collected from water troughs in BC and DL systems. The mean count concentrations in BC $\left(1.4 \times 10^{6}, 7.2 \times 10^{6}\right.$ and $\left.3.4 \times 106\right)$ were relatively higher than those recorded in DL $\left(1.57 \times 10^{7}, 4.52 \times 10^{7}\right.$, and $\left.1.2 \times 10^{6}\right)$.This may be why the body weight of chicken from DL systems was higher as echoed by ( Adam, 2017). The results contradicts reports from Folorunso et al., (2014).All the values (concentrations) recorded were high, similar to a Southeastern study reported by Folorunso et al., (2014).This finding points to a contamination point(s) /(sources) that endanger the quality of drinking water in the study birds and can ultimately harm production and public health (ICG, 1999;

Abbas et al., 2008; Food Standards Australia New Zealand, 2008). Microbes in water or other contacts with the bird enters eggs and kill them or make them unhealthy to consumers (Abbas et al., 2008).

\begin{tabular}{|c|c|c|c|c|c|}
\hline $\begin{array}{l}\text { Housing } \\
\text { system }\end{array}$ & Farm & Weeks & $\begin{array}{l}\text { No. of } \\
\text { colonies }\end{array}$ & $\begin{array}{l}\text { Mean count } \\
(\mathrm{cfu} / \mathrm{ml})\end{array}$ & $\begin{array}{l}\text { Standard } \\
\text { (cfu/ml) }\end{array}$ \\
\hline \multirow{9}{*}{$\begin{array}{l}\text { Battery } \\
\text { cage }\end{array}$} & Farm 1 & Week 1 & 15 & \multirow{4}{*}{$1.4 \times 10^{6}$} & $1.5 \times 10^{6}$ \\
\hline & & Week 2 & 12 & & $1.2 \times 10^{6}$ \\
\hline & & Week 3 & 15 & & $1.5 \times 10^{6}$ \\
\hline & Farm 2 & Week 1 & 124 & & $1.24 \times 10^{7}$ \\
\hline & & Week 2 & 61 & \multirow[t]{2}{*}{$7.2 \times 10^{6}$} & $6.1 \times 10^{6}$ \\
\hline & & Week 3 & 320 & & $3.20 \times 10^{7}$ \\
\hline & Farm 3 & Week 1 & 96 & \multirow{3}{*}{$3.4 \times 10^{6}$} & $9.6 \times 10^{6}$ \\
\hline & & Week 2 & 3 & & $0.3 \times 10^{5}$ \\
\hline & & Week 3 & 3 & & $0.3 \times 10^{5}$ \\
\hline \multirow{9}{*}{$\begin{array}{l}\text { Deep } \\
\text { litter }\end{array}$} & Farm 1 & Week 1 & 51 & \multirow{4}{*}{$1.57 \times 10^{7}$} & $5.1 \times 10^{6}$ \\
\hline & & Week 2 & 194 & & $1.94 \times 10^{7}$ \\
\hline & & Week 3 & 228 & & $2.28 \times 10^{7}$ \\
\hline & Farm 2 & Week 1 & 640 & & $6.40 \times 10^{7}$ \\
\hline & & Week 2 & 111 & \multirow[t]{2}{*}{$4.52 \times 10^{7}$} & $1.11 \times 10^{7}$ \\
\hline & & Week 3 & 606 & & $6.05 \times 10^{7}$ \\
\hline & Farm 3 & Week 1 & 8 & \multirow{3}{*}{$1.2 \times 10^{6}$} & $0.8 \times 10^{5}$ \\
\hline & & Week 2 & 22 & & $2.2 \times 10^{6}$ \\
\hline & & Week 3 & 7 & & $0.7 \times 10^{5}$ \\
\hline
\end{tabular}

In table 2, the bacterial species associated with $\mathrm{BC}$ and DL systems of this study were shown. The mean count (CFU/ml) for BC was 72.11111 and that of DL was 207.4444. The bacteria determined in BC envisaged : Bacillus species, Micrococcus varians, Corynebacterium xerosis and Lactobacillus fermenti; whereas, those determined in DL are Micrococcus varians, Lactobacillus fermenti, E. coli, and Corynebacterium xerosis; thus E. coli was only recorded in DC, but the rest were found in both BC and DL. Folorunso et al., (2014), observed E.coli, Bacillus species, and Corynebacterium species. Table 3 depicted the frequency of occurrence of the bacterial species in BC and DL systems of this study. In BC, the most frequent was Corynebacterium xerosis, then Micrococcus varians, and lastly Bacillus species and Lactobacillus fermenti; whereas, in DL Corynebacterium xerosis was also most frequent, then Micrococcus varians, then the rests. Thus, Corynebacterium xerosis was the most overall prevalent, then $M$. varians, then the rests. Sule and Ilori (2017) determined Micrococcus species (more particularly M.varians) from poultry feed in Ilorin Nigeria. Lactobacillus bacteria are nonpathogenic microbes that naturally inhabits the mucous of humans and animals (including chickens) providing a protective barrier in the gut. 


\begin{tabular}{|c|c|c|c|c|c|c|}
\hline $\begin{array}{l}\text { Housing } \\
\text { system }\end{array}$ & Farm & Weeks & $\begin{array}{l}\text { Range count } \\
\text { (cfu/ml) }\end{array}$ & & & Bacteria species \\
\hline \multirow{7}{*}{$\begin{array}{l}\text { Battery } \\
\text { cage }\end{array}$} & Farm 1 & Week 1 & $1.5 \times 10^{6}$ & \multirow{6}{*}{72.11111} & \multirow{6}{*}{102.79} & Bacillus species \\
\hline & & Week 2 & $1.5 \times 10^{6}$ & & & Micrococcus varians \\
\hline & & Week 3 & $1.2 \times 10^{6}$ & & & Corynebacterium xerosis \\
\hline & Farm 2 & Week 1 & $3.20 \times 10^{7}$ & & & Lactobacillus fermenti \\
\hline & & Week 2 & $1.24 \times 10^{7}$ & & & Corynebacterium xerosis \\
\hline & & Week 3 & $6.1 \times 10^{6}$ & & & \\
\hline & Farm 3 & Week 1 & $9.6 \times 10^{6}$ & \multirow{12}{*}{207.4444} & \multirow{12}{*}{248.67} & Corynebacterium xerosis \\
\hline \multirow{11}{*}{$\begin{array}{l}\text { Deep } \\
\text { litter }\end{array}$} & & Week 2 & $0.3 \times 10^{5}$ & & & Micrococcus varians \\
\hline & & Week 3 & $0.3 \times 10^{5}$ & & & \\
\hline & Farm 1 & Week 1 & $2.28 \times 10^{7}$ & & & Corynebacterium xerosis \\
\hline & & Week 2 & $1.97 \times 10^{7}$ & & & Micrococcus varians \\
\hline & & Week 3 & $5.1 \times 10^{7}$ & & & \\
\hline & Farm 2 & Week 1 & $6.40 \times 10^{7}$ & & & Micrococcus varians \\
\hline & & Week 2 & $6.06 \times 10^{7}$ & & & Lactobacillus fermenti \\
\hline & & Week 3 & $1.11 \times 10^{7}$ & & & \\
\hline & Farm 3 & Week 1 & $2.2 \times 10^{6}$ & & & Escherichia coli \\
\hline & & Week 2 & $0.8 \times 10^{5}$ & & & Bacillus species \\
\hline & & Week 3 & $0.7 \times 10^{5}$ & & & Corynebacterium xerosis \\
\hline
\end{tabular}

Table 3: Frequency of occurrence of bacterial species from BC and DL systems in Sokoto Metropolis

\begin{tabular}{|c|c|c|c|c|c|}
\hline $\begin{array}{l}\text { Housing } \\
\text { system }\end{array}$ & Farm & Weeks & Bacteria species & Frequency & Percentage \\
\hline \multirow{6}{*}{$\begin{array}{l}\text { Battery } \\
\text { cage }\end{array}$} & \multirow[t]{3}{*}{ Farm 1} & Week 1 & Bacillus species & 1 & 14.2 \\
\hline & & Week 2 & Micrococcus varians & 2 & 28.5 \\
\hline & & Week 3 & Corynebacterium xerosis & 3 & 42.8 \\
\hline & \multirow[t]{2}{*}{ Farm 2} & Week 1 & Corynebacterium xerosis & & \\
\hline & & $\begin{array}{l}\text { Week } 2 \\
\text { Week } 3\end{array}$ & Lactobacillus fermenti & 1 & 14.2 \\
\hline & \multirow[t]{2}{*}{ Farm 3} & Week 1 & Corynebacterium xerosis & & \\
\hline \multirow{10}{*}{$\begin{array}{l}\text { Deep } \\
\text { litter }\end{array}$} & & $\begin{array}{l}\text { Week } 2 \\
\text { Week } 3\end{array}$ & Micrococcus varians & & \\
\hline & \multirow[t]{3}{*}{ Farm 1} & Week 1 & Corynebacterium xerosis & 3 & 37.5 \\
\hline & & Week 2 & Micrococcus varians & 2 & 25 \\
\hline & & Week 3 & Corynebacterium xerosis & & \\
\hline & \multirow[t]{3}{*}{ Farm 2} & Week 1 & Lactobacillus fermenti & 1 & 12.5 \\
\hline & & Week 2 & & & \\
\hline & & Week 3 & Microbacterium varians & & \\
\hline & \multirow[t]{3}{*}{ Farm 3} & Week 1 & Corynebacterium xerosis & & \\
\hline & & Week 2 & Escherichia coli & 1 & 12.5 \\
\hline & & Week 3 & Bacillus species & 1 & 12.5 \\
\hline
\end{tabular}

It eliminate unfavourable microflora through diverse mechanisms such as production of organic acids, hydrogen peroxide, etc as inhibitors; blocking adhesion sites of epithelial, competition for nutrients and triggering of immunity. Thus, it is administered as probiotic in chicken's feed. Therefore, it is not uncommon to determine it in drinking water in this study (Gusils et al., 1998; Dec et al., 2018). Some $E$. coli (parable, Avian Pathogenic E. coli, APEC) causes collibacillosis, a major bacterial disease of poultry worldwide and it is communicable to humans .Some E.coli can traverse to all organs (in birds) and cause fatal disease ( Ibrahim et al., 2019). E. coli commonly form biofilm, an assembly of microbial cells that is surrounded by a matrix of extraplomeric substance released by the cells. It can stay alone or attract other microbes. Growing in biofilms confers intrinsically more resistance to antimicrobials of about 1,000 fold; therefore need more drugs (Ugwoke, et al., 2019). E .coli reduces weight of poultry (Elsaidy et al., 2015). E. coli in poultry water was determined by past studies such as Ibitoye et al., (2013) from Sokoto. Aliyu et al., (2012) determined it in diverse poultry feeds in Sokoto. Bacillus species are responsible for food poisoning in many cases (Cunningham, 1982). Aliyu et al., (2013) observed them in poultry feed in Sokoto. Corynebacterium xerosis is part of the genus of Corynebacterium species, which have been reported in chicken and have been suspected for causing food poisoning and spoilage and it remained as an indicator of unsanitary food handling (Alibi et al., 2016). 
Table 4: Biochemical characterization of bacterial species identified from farms at Sokoto metropolis

\begin{tabular}{|c|c|c|c|c|c|c|c|c|c|c|c|c|c|c|c|c|}
\hline Sample type & Gram reaction & Catalase & SH & Lactose & Glucose & Sucrose & Citrate & Motility & Indole & Urease & MR & VP & $\mathrm{H} 2 \mathrm{~S}$ & Gas & Spore & Confirmation \\
\hline $\mathrm{BC} 1^{1}$ & + rod & + & - & - & + & - & LR & - & + & - & + & - & - & - & + & Bacillus species \\
\hline $\mathrm{BC}^{2}$ & + cocci & + & NA & + & - & - & + & + & + & + & - & + & - & - & - & $\begin{array}{l}\text { Micrococcus } \\
\text { xerosis }\end{array}$ \\
\hline $\mathrm{BC} 1^{3}$ & - rod & + & - & + & - & - & - & + & + & SR & - & + & - & - & - & $\begin{array}{l}\text { Corynebacterium } \\
\text { xerosis }\end{array}$ \\
\hline $\mathrm{DL} 1^{1}$ & $+\operatorname{rod}$ & + & - & + & - & + & SR & + & + & SR & + & - & - & - & - & $\begin{array}{l}\text { Corynebacterium } \\
\text { xerosi }\end{array}$ \\
\hline $\mathrm{DL}^{2}$ & + cocci & + & NA & + & + & + & - & + & + & - & - & + & - & - & - & $\begin{array}{l}\text { Micrococcus } \\
\text { varians }\end{array}$ \\
\hline $\mathrm{BC} 2^{1}$ & $+\operatorname{rod}$ & + & - & + & + & - & + & + & + & - & + & - & - & - & - & $\begin{array}{l}\text { Corynebacterium } \\
\text { xerosis }\end{array}$ \\
\hline $\mathrm{BC} 2^{2}$ & $+\operatorname{rod}$ & + & - & + & + & - & - & + & - & SR & - & + & - & - & + & $\begin{array}{l}\text { Lactobacillum } \\
\text { fermenti }\end{array}$ \\
\hline $\mathrm{DL}^{3}$ & + rod & + & - & + & - & + & - & - & + & - & - & + & - & - & - & $\begin{array}{l}\text { Corynebacterium } \\
\text { xerosis }\end{array}$ \\
\hline DL2 $^{1}$ & + rod & + & - & + & + & + & - & + & + & SR & - & + & - & - & - & $\begin{array}{l}\text { Lactobacillus } \\
\text { fermenti }\end{array}$ \\
\hline DL2 ${ }^{3}$ & + cocci & + & NA & + & + & + & - & + & + & + & - & + & - & - & - & $\begin{array}{l}\text { Micrococcus } \\
\text { varians }\end{array}$ \\
\hline $\mathrm{BC} 3^{1}$ & + rod & + & - & - & + & - & - & + & + & - & + & - & - & - & + & $\begin{array}{l}\text { Corynebacterium } \\
\text { xerosis }\end{array}$ \\
\hline $\mathrm{BC}^{2}$ & $+\operatorname{cocci}$ & + & NA & + & + & - & - & + & + & - & - & + & - & - & - & $\begin{array}{l}\text { Micrococcus } \\
\text { varians }\end{array}$ \\
\hline DL $3^{1}$ & $+\operatorname{rod}$ & + & - & + & + & + & - & + & + & - & - & + & - & - & - & $\begin{array}{l}\text { Corynebacterium } \\
\text { xerosis }\end{array}$ \\
\hline DL $^{2}$ & -rod & + & NA & + & + & + & LR & + & + & + & - & + & + & - & - & E.coli \\
\hline DL3 $^{3}$ & + rod & + & - & - & - & - & - & - & + & + & - & + & - & - & + & Bacillus species \\
\hline
\end{tabular}

KEY: $M R=$ methyl red $V P=$ vokes-proskeur $N A=$ not applicable $S R=$ slow reaction $L R=$ low reaction $B C=$ attery cage $D L=$ deep litter

This work illustrated that water used in the BC and DL systems surveyed contains a higher and diverse concentration of bacteria namely, Bacillus species, Corynebacterium xerosis, Micrococcus varians, E.coli, and Bacillus species.

This is a portend of contamination and unsanitary outcome which is capable of harming the health, production, and ultimately the public health. Ideally, points of contamination in water are diverse. The source of water (e.g. well, pipeborne),improper cleaning and maintenance of drinkers or rearing place, feeds, drugs, faeces ,farmers awareness or education are among the factors that triggers water contamination. Therefore, farmers should be made aware ,and innovative systems of water treatment should be applied, proper cleaning of drinkers and cages or farms are mostly needed in order to safeguard poultry production and public health ( Cunningham,1982; Amaral ,2005; Uwaezuoke and Ogbulie, 2008; Aliyu et al .,2013; Dhaka et al .,2013; Ibitoye et al ., 2013; Elsaidy et al., 2015; Sarkingobir and Sarkingobir, 2017; Sarkingobir et al., 2019).

Conclusion: The microbes determined in this study were in high concentration, therefore the affected waters were contaminated. 


\section{REFERENCES}

Abbas, TEE; Elzubeir, EA; Arabbi, OH (2008). Drinking water quality and its effects on broiler performance during winter season. Int. J. Poultry. Sci., 7(5):433-39.

Adam, IYI (2017). Effects of deep litter floor and battery cages system on the productive performance of commercial layers in Elabied, Suda. A thesis submitted at University of Kordofan.

Alibi, S; Ferjani, A; Boukadida, J (2016). Implication of Corynebacterium species in foods contamination. J. Coastal Life Med. 4(5): 416-419

Aliyu, RM; Egwu, EO; Abubakar, MB; Adamu, AY; Salihu, MD; Dabai, AI; and Tambuwal, FM (2013). Bacteriological quality of commercially prepared and self-compounded poultry feeds in Sokoto Metropolis, Sokoto, Nigeria. Int. J. Appl. Biol. Pharma. Technol. 3(1): 345-350

Amaral LA do (2005). Drinking water as a risk factor to poultry health. Braz. J. Poul. Sci., 6(4):191-199.

Cunningham, FE (1982). Microbiological aspects of poultry products: An updated. Food Protec. 45:1149-194.

Cheesbrough, M (2009). District laboratory practice in tropical countries (part 1), 2nd edition. USA,Cambridge University Press.

Dhaka, KS; Chakraborty, R; Barathidasan, R; Tiwari, R; Rajagunalan, S; Sigh SD (2013).E. coli , an economically important avian pathogen, it's disease manifestations, diagnosis, and control ,and public health significance : A review.Res. Opin. Ani. Vet. Sci. 3(6):179-194.

Dec, M; Nowaczek, A; Urbanchmiel, R; Stepienpysniak, D; Wernicki, A (20018). Probiotic potential of Lactobacillus isolates of chicken origin with antiCampylobacter activity. J. Vet. Med. Sci. 80(8):1195-1203.

Downes,I (2001). Compendium of methods for the microbiological examination of foods, 4th edition. American Public Health Association, Washington D.C, USA.

Elsaidy, N; Mohammed, RA; Aboulemien, F (2015). Assessment of variable drinking water sources used in Egypt on broiler health and welfare. Vet. World. 8(7): 855-864.
Folorunso, OR; Sule, K; Onibon, VO (2014). Poultry farm hygiene: microbial quality assessment of drinking water used in layer chickens managed under the battery cage and deeply litter systems at three poultry farms in southern Nigeria. Pak. J. of Biol. Sci. 17 (1):74-79.

Food Standards Australia New Zealand (2008). Scientific assessment of the public health and safety of poultry meat in Australia.

Gusils, G; Chaia, AP; Gonzalez, S; Oliver, C (1998). Lactobacilli isolated from chicken industries: potential use as probiotics. J. Food Protec. 62(2):252-256.

Ibitoye, EB; Dabai, YU; Midi, L (2013). Evaluation of different drinking water sources in Sokoto Northwest Nigeria on performance, carcass traits and haematology of broiler chickens. Vet. World 6(11):879-883.

Ibrahim, RA; Cryer, TL; Lafi, SQ; Basha, E; Good, L; Tarazi, YH (2019). Identification of $E$. coli from broiler chickens in Jordan, their antimicrobial resistance, gene characterization and the associated risk factors. BMC Vet. Res. 15 (159): 116.

International Consultative Group on Food Irradiation (1999). Safety of poultry meat: from farm to table.

HiMedia Laboratories (2019). Simmons Citrate agar.www.himedialabs.com.

HiMedia Laboratories (2015). Triple Sugar Iron Agar medium.

Microbiology Society (2016). Basic practical microbiology: a manual. Microbiology Society, Charles Darwin House, London, UK.

MacWilliams, MP (2009). Indole test protocol. American Society for Microbiology.

Oviasogie, FE; Ogboghodo, IB; Beshiru, A; Omoregie, BO; Ogofure, P; Ogofure, AG (2016). The microbial burden load of eggshells from different poultry rearing systems in Ekosodin village, Edo state, Nigeria. J. Appl. Sci. Environ. Manage. 20(2):227-231.

Sarkingobir, Y; Saharu, AU; Zayyanu, MM (2019). Survey of water, sanitation, and hygiene (WASH) in primary schools in Sokoto state, Nigeria. Int. J. Educ. Res. Stud. 1(1):26-29. 
Sarkingobir, Y; Sarkingobir, S (2017). Open defecation, a threat to public health and Sustainable Development Goals: a case study of Gwadabawa local government, Sokoto state, Nigeria. Int. J. Med. Biosc.1 (1):1-10.

Sule, IO; Ilori, IO (2017). Microbiological assessment of poultry feeds within Ilorin, Nigeria. Not. Sci. Biol. 9(1):34-39.

The PEW Charitable Trusts (2016). Emerging pathogens in meat and poultry.Www.Pewtrusts.org/seafood Tand poultry.www.org/.
Ugwoke, MI; Machido, DA; Tijjani, MB (2019). Evaluation of the biofilm forming capacities of bacterial isolates recovered in two and treated effluent from wastewater treatment plant of Ahmadu Bello University Zaria, Nigeria. J. Appl. Sci. Environ. Manage. 23(10):1783-1786.

Uwaezuoke, JC; Ogbulie, JN (2008). Microbial quality of commercially available poultry feeds sold in parts of eastern Nigeria. J. Appl. Sci. Environ. Manage. 12 (1):113-117.

Ventura daSilva, MC (2013).Consumption.Food and Agriculture Organization of the United Poultry Development Review. 